NOTE

\title{
Association of Type III secretion genes with virulence of Aeromonas salmonicida subsp. salmonicida
}

\author{
Sarah E. Burr ${ }^{1}$, Thomas Wahli ${ }^{2}$, Helmut Segner ${ }^{2}$, Dmitri Pugovkin ${ }^{2}$, Joachim Frey ${ }^{1, *}$ \\ ${ }^{1}$ Institute of Veterinary Bacteriology, and ${ }^{2}$ Centre for Fish and Wildlife Health, \\ Institute of Animal Pathology, University of Berne, Laenggassstrasse 122, 3012 Berne, Switzerland
}

\begin{abstract}
Aeromonas salmonicida subsp. salmonicida possesses a number of potential virulence factors, including a recently identified plasmid-encoded Type III secretion system. A number of field isolates of A. salmonicida subsp. salmonicida were examined for the presence of Type III secretion genes. Using in vitro experiments, it was found that field isolates containing such genes are cytotoxic to fish cell lines, whereas those that lack these genes are not. Using a rainbow trout in vivo model, the virulence of a wild type A. salmonicida subsp. salmonicida strain (Strain JF2267), which possesses Type III secretion genes, was compared to that of a laboratory derivative of the same strain that has lost these genes. While Strain JF2267 was virulent towards rainbow trout, its derivative was not. The A. salmonicida subsp. salmonicida Type Strain ATCC $33658^{\mathrm{T}}$, which also lacks Type III secretion genes, was also found to be avirulent by this challenge model. The findings from both the in vitro and in vivo experiments suggest that the presence of Type III secretion genes is associated with the virulence of this important fish pathogen.
\end{abstract}

KEY WORDS: In vivo · In vitro · Virulence · Furunculosis · Type III protein secretion

\section{INTRODUCTION}

Aeromonas salmonicida subsp. salmonicida is one of the most extensively studied fish pathogens due to its widespread distribution and its economic impact on aquaculture. This bacterium is the causative agent of furunculosis, a systemic disease primarily affecting salmonids. In spite of the fact that $A$. salmonicida was first identified over a century ago (Emmerich \& Weibel 1894), very little is known about its virulence mechanisms. A number of potential virulence factors are produced by A. salmonicida subsp. salmonicida. These include bacterial surface structures such as the surface layer or A-layer protein (Chu et al. 1991), lipopolysaccharide (Lee \& Ellis 1990) and Type IV pili (Masada et al. 2002). The bacterium also secretes a number of extracellular proteins, including haemolysins (Nomura et al. 1988, Hirono \& Aoki 1993) and proteases (Whitby et al. 1992). A Type III secretion system (TTSS) has also recently been identified in A. salmonicida subsp. salmonicida Strain JF2267, a strain originally isolated from an arctic char Savelinus alpinus presenting typical furunculosis symptoms (Braun et al. 2002, Burr et al. 2002).

TTSSs are important virulence attributes of several Gram-negative bacteria, including Salmonella typhimurium, Shigella flexneri, Escherichia coli and the pathogenic Yersinia species. These secretion systems function by moving effector molecules, produced in the bacterial cytosol, across both the inner and outer bacterial membranes, and directly into the cytosol of target eukaryotic cells. Once in the target cell, the effector molecules are able to disrupt the cytoskeleton and modulate cell-signalling cascades (for a comprehensive review see (Cornelis \& Van Gijsegem 2000). 
In Aeromonas salmonicida subsp. salmonicida, the genes encoding the TTSS are found as a gene cluster on a large plasmid of approximately $140 \mathrm{~kb}$ (Stuber et al. 2003a). In this study, we examined field isolates of A. salmonicida subsp. salmonicida for the presence of these TTSS genes.

\section{MATERIALS AND METHODS}

A summary of all Aeromonas salmonicida subsp. salmonicida strains used in this study is provided in Table 1. Strains were cultured on Luria-Bertani (LB) agar plates at $18^{\circ} \mathrm{C}$.

Total DNA was extracted using the guanidium hydrochloride method (Pitcher et al. 1989). Restriction digestion with BamHI and Southern blot hybridization was carried out using standard methods (Ausubel et al. 1999). For the production of a digoxigenin-11-dUTP (DIG)-labeled probe against $a s c V$, PCR was carried out in the presence of $40 \mu \mathrm{M}$ DIG (Roche Diagnostics) using Primers AslcrD-L (GCCCGTTTTGCCTATCAA) and AslcrD-R (GCGCCGATATCGGTACCC) and $20 \mathrm{ng}$ DNA from Strain JF2267 as a template.

Epithelioma papulosum cyprini cells (EPC; ECACC 93120820) and rainbow trout Oncorhynchus mykiss gonad cells (RTG-2; ATCC CCL-55) were grown as described previously (Braun et al. 2002). Two days before infection, the cells were trypsinized and seeded into 24-well culture plates. Monolayered cells $\left(8 \times 10^{5}\right.$ EPC cells or $6 \times 10^{5}$ RTG- 2 cells per $2 \mathrm{~cm}^{2}$ well in $1 \mathrm{ml}$ supplemented medium in each well) were infected with Aeromonas salmonicida subsp. salmonicida suspended in phosphate buffered saline (PBS), pH 7.4, at a multiplicity of infection of 20:1 (bacteria:fish cells). The addition of PBS, pH 7.4, to fish cells was used as a negative control. Following infection at $18^{\circ} \mathrm{C}$, cells

Table 1. Aeromonas salmonicida subsp. salmonicida strains. ATCC: American Type Culture Collection

\begin{tabular}{|lll|}
\hline Strain & \multicolumn{1}{c|}{ Origin } & \multicolumn{1}{c|}{$\begin{array}{c}\text { Source or } \\
\text { Reference }\end{array}$} \\
\hline CC-23 & Norway & William Kay $^{\mathrm{a}}$ \\
CC-24 & Norway & William Kay $^{\mathrm{a}}$ \\
CC-27 & Norway & William Kay $^{\mathrm{a}}$ \\
CC-29 & Scotland & William Kay $^{\mathrm{a}}$ \\
CC-63 & Canada & William Kay \\
CC-72 & Canada & William Kay \\
SS70.1 & Laboratory derivative & Hackett et al. (1984) \\
JF2267 & Switzerland & Braun et al. (2002) \\
JF2397 & Derived from JF2267 & Stuber et al. (2003a) \\
ATCC 33658 & Type strain & ATCC \\
aMicrotek & International, Saanichton, & British Columbia, \\
Canada & & \\
\hline
\end{tabular}

were monitored under light microscopy for signs of cell rounding and retraction normally induced by the wild type (wt) Strain JF2267.

A total of 160 six mo old rainbow trout of $7.5 \pm 1.5 \mathrm{~cm}$ total length were randomly distributed in groups of 20 fish and stocked in aerated PVC-tanks of 131 volume. Flow through of tap water was set at $0.61 \mathrm{~min}^{-1}$ and the temperature range during the experiment was $18 \pm$ $0.8^{\circ} \mathrm{C}$. The trout were fed a commercial fish diet at $1 \%$ body weight $\mathrm{d}^{-1}$. Fish were acclimated to the tanks for 2 wk before the experiment began. Aeromonas salmonicida subsp. salmonicida Strains JF2267, JF2397 and ATCC $33658^{\mathrm{T}}$ were grown on LB agar plates for $2 \mathrm{~d}$ at $18^{\circ} \mathrm{C}$. Bacterial suspensions were then prepared in PBS, $\mathrm{pH} 7.4$, to a bacterial concentration of $1 \times 10^{5}$ colony forming units (cfu) $50 \mu \mathrm{l}^{-1}$. The fish (2 tanks per group) were then intraperitoneally injected with $50 \mu \mathrm{l}$ of the appropriate bacterial suspension. A control group was inoculated with $50 \mu \mathrm{l}$ PBS only. Mortality was recorded daily, or in cases of high mortality, twice per day, for $3 \mathrm{wk}$. Dead fish were investigated for the presence of $A$. salmonicida subsp. salmonicida, as were 5 of the surviving fish from each tank (where available) at the end of the experiment.

\section{RESULTS}

Evidence for Type III secretion genes in field isolates of Aeromonas salmonicida subsp. salmonicida. A number of field strains of A. salmonicida subsp. salmonicida (Table 1) were examined for the presence of the TTSS gene ascV using restriction digestion and Southern blot hybridization of total DNA. Five of the 7 field isolates we examined hybridized with the ascV probe (Isolates CC-23, CC-27, CC-29, CC-63 and CC72; Fig. 1), indicating that they possess this gene and by extension, a TTSS (Stuber et al. 2003). Strain JF2267, which was already known to possess a functional TTSS (Burr et al. 2002), also gave a positive signal. In contrast, the Field Strain CC-24 did not hybridize with the ascV probe, nor did Strain SS70.1, suggesting a TTSS is absent in these strains. Likewise, Strains JF2397 (a laboratory strain derived from Strain JF2267 by repeated passaging at $25^{\circ} \mathrm{C}$ ) and ATCC $33658^{\mathrm{T}}$ (the A. salmonicida subsp. salmonicida type strain) did not react with the $a s c V$ probe; this result was expected as these 2 strains have previously been shown to lack the plasmid that codes for the TTSS (Stuber et al. 2003a).

Association of Type III secretion genes with cytotoxicity towards fish cells. A fish-cell infection model was used to determine whether the presence of such secretion genes could be correlated with virulence. Aeromonas salmonicida subsp. salmonicida strains 


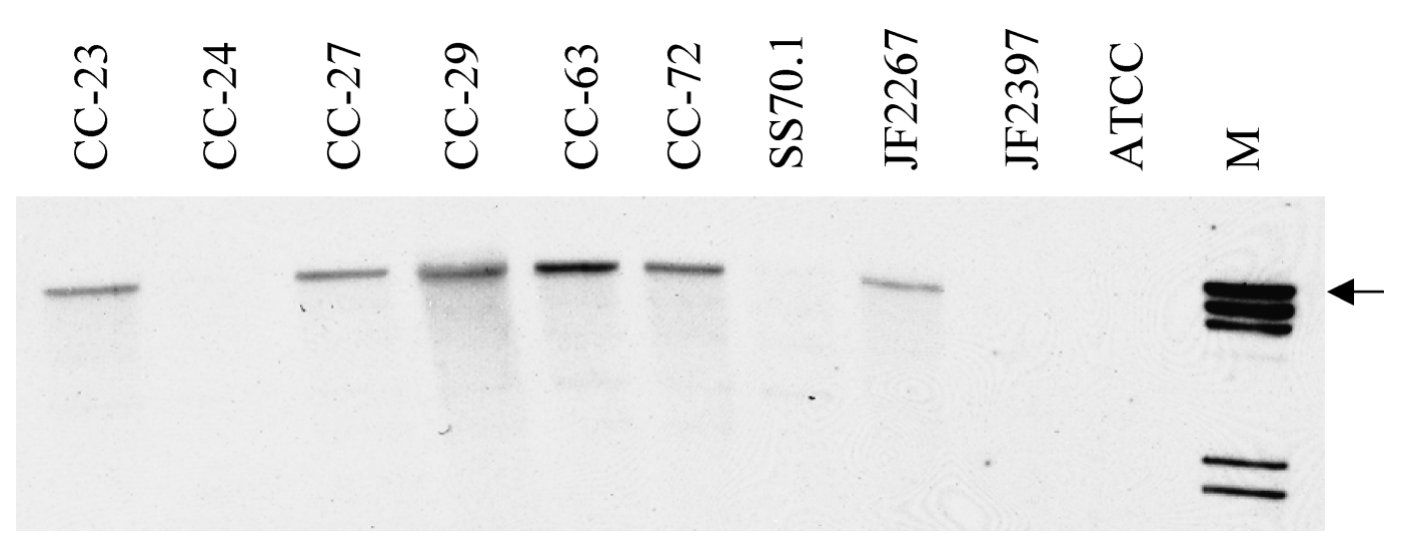

Fig. 1. Aeromonas salmonicida subsp. salmonicida. Evidence for Type III secretion genes in isolates. Total DNA extracted from A. salmonicida subsp. salmonicida strains and digested with BamHI was analyzed by Southern blot using a digoxigenin-11-dUTP (DIG)-labeled probe against the Type III secretion gene ascV. Strain names are indicated; ATCC refers to Type Strain ATCC $33658^{\mathrm{T}}$. Lane M contains lamda phage DNA digested with HindIII; fragment sizes (from top to bottom) are 23.1 (marked by arrow), $9.4,6.5,2.3$, and $2.0 \mathrm{~kb}$

were tested for cytotoxicity against EPC and RTG-2 fish cell lines; the results are summarized in Table 2. The Field Strains CC-23, CC-27, CC-29, CC-63 and CC-72 were toxic for both the EPC and RTG-2 cell lines, as evidenced by induction of cell rounding and detachment from the plastic support. These morphological changes could be detected as little as $2 \mathrm{~h}$ following inoculation, and were also apparent in the Control Strain JF2267. In contrast, infection with Strains CC-24 and SS70.1 did not result in any morphological changes; $6 \mathrm{~h}$ following infection, fish cells inoculated with these strains looked similar in appearance to the control cells that were inoculated with PBS only.

Table 2. Aeromonas salmonicida subsp. salmonicida infecting Epithelioma papulosum cyprini cells (EPC) or rainbow trout Oncorhynchus mykiss gonad cells (RTG-2). PBS was used as a negative control; cells were inoculated with PBS only. +: infection resulted in cell-rounding and retraction; -: infection resulted in no morphological changes; NA: not applicable

\begin{tabular}{|lccc|}
\hline \multirow{2}{*}{ Strain } & \multirow{2}{*}{ Type III } & \multicolumn{2}{c|}{ Toxicity } \\
& Secretion genes & EPC & RTG-2 \\
\hline CC-23 & + & + & + \\
CC-24 & - & - & - \\
CC-27 & + & + & + \\
CC-29 & + & + & + \\
CC-63 & + & + & + \\
CC-72 & + & + & + \\
SS70.1 & - & - & - \\
JF2267 & + & + & + \\
JF2397 & - & - & - \\
ATCC 33658 & - & - & - \\
PBS & - & - & - \\
& NA & & \\
\hline
\end{tabular}

Strains JF2397 and ATCC $33658^{\mathrm{T}}$ were also non-toxic towards both cell lines. In each case, the strains that displayed toxicity towards the EPC and RTG-2 cells were those that were found to possess TTSS genes. Those strains that did not have a toxic effect towards the fish cell lines lacked these genes. This result suggests that the presence of TTSS genes in A. salmonicida subsp. salmonicida is associated with cytotoxicity towards fish cells.

Association of Type III secretion genes with virulence towards rainbow trout. To assess the possibility that the presence of TTSS genes is associated with virulence in vivo, we utilized a rainbow trout infection model to compare the virulence of the wt isolate (JF2267), which possesses TTSS genes, to its derivative strain (JF2397), which lost the plasmid that encodes the TTSS genes following laboratory cultivation at $25^{\circ} \mathrm{C}$. Strain ATCC $33658^{\mathrm{T}}$ was also included in the assay.

The results, displayed in Fig. 2, indicate that the onset of mortality in fish infected with the wt Strain JF2267 began 2 d following infection. Within $3 \mathrm{~d}$, all fish (in both tanks) that had been injected with this strain had died. The dead fish showed only minor macroscopic alterations, such as slight haemorrhages in the perivisceral fat and the intestines, a swollen vent and protruding anus. These symptoms correspond to those described by Hiney \& Olivier (1999) for acute furunculosis. Aeromonas salmonicida subsp. salmonicida could be cultured from all of these dead fish. In contrast, no mortalities occurred in any of the fish injected with the laboratory derivative JF2397 or Strain ATCC $33658^{\mathrm{T}}$ (Fig. 2). Furthermore, A. salmonicida subsp. salmonicida could not be isolated from any 


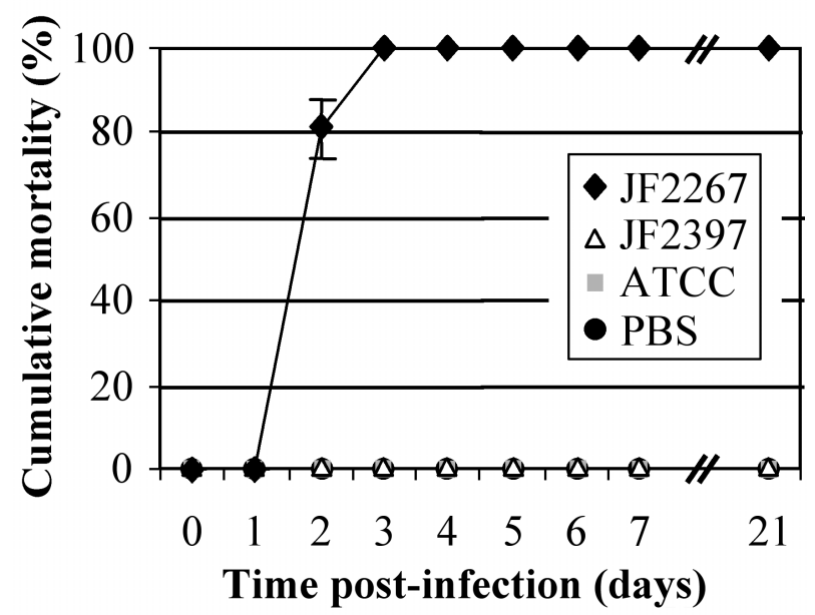

Fig. 2. Cumulative mortality resulting from challenge of rainbow trout Oncorhynchus mykiss with isolates of Aeromonas salmonicida subsp. salmonicida. Strains used are indicated. Strain JF2267 contains Type III secretion system (TTSS) genes, whereas strains JF2397 and ATCC $33658^{\mathrm{T}}$ do not

of the surviving fish in these groups. As expected, there were no mortalities observed in the control group that was injected with PBS only.

\section{DISCUSSION}

Although Aeromonas salmonicida subsp. salmonicida is an important and economically significant fish pathogen, surprisingly little is known about its pathogenicity. While the bacterium produces many potential virulence factors, inactivation of several of these factors does not have a marked effect on virulence (Vipond et al. 1998, Masada et al. 2002). The role of the well characterized surface-layer protein (A-layer) is also unclear. While certain A-layer-deficient strains are avirulent (Noonan \& Trust 1995), others are in fact virulent (Adams et al. 1988, Ellis et al. 1988, Bernoth 1990). There have also been reports of A-layer-positive strains that are avirulent (Adams et al. 1988). Strain SS70.1, examined in this study, is one such strain. This strain is positive for a number of suspected virulence factors: A-layer and lipopolysaccharide, as well as protease, elastase, lecithinase, and haemolysin activity (Olivier et al. 1992). However, this strain lacks the TTSS, as shown by the absence of the ascV gene by Southern blot analysis, and was not cytotoxic in our cell assays. It has also previously been shown to be avirulent to brook trout Salvelinus fontinalis when injected intraperitoneally (Olivier 1990).

In this study, we have used a probe against the TTSS gene $a s c V$ to determine whether TTSSs are present in field isolates of Aeromonas salmonicida subsp. salmon- cida. This gene encodes $\mathrm{AscV}$, an inner membrane component of the Type III secretion apparatus. AscV and its homologues are members of a highly conserved family of proteins found in every known TTSS; all members can be aligned over the entire length of their amino acid sequence (Galan et al. 1992, Plano et al. 1991). Because of this, this family of genes can be used as an effective method for screening bacteria for the presence of TTSSs (Stuber et al. 2003). We have shown that 5 field isolates that possess asc $V$ (indicating they contain a TTSS) were all cytotoxic for both EPC and RTG-2 cells in vitro. In contrast, the remaining field isolate (CC-24) lacked ascV and was avirulent towards the same cell lines. The $A$. salmonicida subsp. salmonicida Type Strain ATCC $33658^{\mathrm{T}}$ and Strain SS70.1, which also lack TTSS genes, were also noncytotoxic towards the fish cells. These findings suggest that the TTSS is an important virulence factor.

More importantly, an association between TTSS genes and virulence was found under in vivo conditions. Strain JF2267, which possesses a functional TTSS, was found to be highly virulent towards rainbow trout. In contrast, Strain JF2397 (a derivative of Strain JF2267) lacks the plasmid that codes for the TTSS genes, and was avirulent towards rainbow trout. Strain ATCC $33658^{\mathrm{T}}$, which also lacks TTSS genes, was also avirulent by our challenge method. These results strengthen the argument that the TTSS plays a role in Aeromonas salmonicida subsp. salmonicida pathogenicity. Furthermore, they indicate that laboratory cultivation of A. salmonicida subsp. salmonicida can have a dramatic effect on the virulence of the organism.

Loss of virulence as a result of laboratory subculture of Aeromonas salmonicida has been previously described. It has long been known that growth of $A$. salmonicida at elevated temperatures (above $27^{\circ} \mathrm{C}$ ) results in the loss of A-layer (Ishiguro et al. 1981). In fact, serial passaging of A-layer-positive strains at $28^{\circ} \mathrm{C}$ has been used to generate A-layer-minus strains in order to study the role of the A-layer in virulence (Olivier 1990). However, this method likely also results in the loss of TTSS genes, as these genes are located on a thermosensitive plasmid that is lost at temperatures above $20^{\circ} \mathrm{C}$ (Stuber et al. 2003a); therefore it cannot be used as a reliable method to draw conclusions as to the role that A-layer protein alone plays in virulence.

The results of this study indicate that the presence of TTSS genes is associated with pathogenicity of Aeromonas salmonicida subsp. salmonicida towards rainbow trout (and potentially other Salmonidae spp.), and that virulence of $A$. salmonicida subsp. salmonicida isolates can be predicated by the presence or absence of these TTSS genes. Furthermore, the correlation we have found between the in vitro and the in vivo exper- 
iments suggests that assaying A. salmonicida subsp. salmonicida virulence in cell culture is a valuable model which can replace in vivo experiments.

Acknowledgements. We are grateful to L. Lagcher, University of Berne, for cultivation of fish cells and to W. Kay, Microtek International, for providing us with field isolates. This work was supported by the research fund of the Institute of Veterinary Bacteriology, University of Berne.

\section{LITERATURE CITED}

Adams A, Bundy A, Thompson K, Horne MT (1988) The association between virulence and cell surface characteristics of Aeromonas salmonicida. Aquaculture 69:1-14

Ausubel FM, Brent R, Kingston RE, Moore DD, Seidman JG, Smith JA, Struhl K (1999) Current protocols in molecular biology. John Wiley \& Sons, New York

Bernoth EM (1990) Autoagglutination, growth on tryptonesoy-Coomassie agar, outer membrane protein patterns and virulence of Aeromonas salmonicida strains. J Fish Dis 13:145-155

Braun M, Stuber K, Schlatter Y, Wahli T, Kuhnert P, Frey $\mathrm{J}$ (2002) Characterization of an ADP-ribosyltransferase toxin (AexT) from Aeromonas salmonicida subsp. salmonicida. J Bacteriol 184:1851-1858

Burr SE, Stuber K, Wahli T, Frey J (2002) Evidence for a type III secretion system in Aeromonas salmonicida subsp. salmonicida. J Bacteriol 184:5966-5970

Chu S, Cavaignac S, Feutrier J, Phipps BM, Kostrzynska M, Kay WW, Trust TJ (1991) Structure of the tetragonal surface virulence array protein and gene of Aeromonas salmonicida. J Biol Chem 266:15258-15265

Cornelis GR, Van Gijsegem F (2000) Assembly and function of type III secretory systems. Annu Rev Microbiol 54: $735-774$

Ellis AE, Burrows AS, Stapleton KJ (1988) Lack of relationship between virulence of Aeromonas salmonicida and the putative virulence factors: A-layer, extracellular proteases and extracellular haemolysins. J Fish Dis 11: 309-323

Emmerich R, Weibel E (1894) Ueber eine durch Bakterien erregte Seuche unter den Forellen. Arch Hyg Bakteriol 21: $1-21$

Galan JE, Ginocchio C, Costeas P (1992) Molecular and functional characterization of the Salmonella invasion gene invA: homology of InvA to members of a new protein family. J Bacteriol 174:4338-4349

Hackett JL, Lynch WH, Paterson WD, Coombs DH (1984) Extracellular protease, extracellular haemolysin, and virulence in Aeromonas salmonicida. Can J Fish Aquat Sci 41: $1354-1360$

Hiney M, Olivier G (1999) Furunculosis (Aeromonas salmonicida). In: Woo PTK, Bruno DW (eds) Fish diseases and dis-

Editorial responsibility: Carey Cunningham,

Aberdeen, UK orders, Vol 3: Viral, bacterial and fungal infections. CAB International, New York, p 341-425

Hirono I, Aoki T (1993) Cloning and characterization of three hemolysin genes from Aeromonas salmonicida. Microb Pathog 15:269-282

Ishiguro EE, Kay WW, Ainsworth T, Chamberlain JB, Austen RA, Buckley JT, Trust TJ (1981) Loss of virulence during culture of Aeromonas salmonicida at high temperature. J Bacteriol 148:333-340

Johnson CM, Tatner MF, Horne MT (1985) Comparison of the surface properties of seven strains of a fish pathogen, Aeromonas salmonicida. J Fish Biol 27:445-458

Lee KK, Ellis AE (1990) Glycerophospholipid:cholesterol acyltransferase complexed with lipopolysaccharide (LPS) is a major lethal exotoxin and cytolysin of Aeromonas salmonicida: LPS stabilizes and enhances toxicity of the enzyme. J Bacteriol 172:5382-5393

Masada CL, LaPatra SE, Morton AW, Strom MS (2002) An Aeromonas salmonicida type IV pilin is required for virulence in rainbow trout Oncorhynchus mykiss. Dis Aquat Org 51:13-25

Nomura S, Fujino M, Yamakawa M, Kawahara E (1988) Purification and characterization of salmolysin, an extracellular hemolytic toxin from Aeromonas salmonicida. J Bacteriol 170:3694-3702

Noonan B, Trust TJ (1995) Molecular analysis of an A-protein secretion mutant of Aeromonas salmonicida reveals a surface layer-specific protein secretion pathway. J Mol Biol 248:316-327

Olivier G (1990) Virulence of Aeromonas salmonicida: lack of relationship with phenotypic characteristics. J Aquat Anim Health 2:119-127

Olivier G, Moore AR, Fildes J (1992) Toxicity of Aeromonas salmonicida cells to Atlantic salmon Salmo salar peritoneal macrophages. Dev Comp Immunol 16:49-61

Pitcher DG, Saunders NA, Owen RJ (1989) Rapid extraction of bacterial genomic DNA with guanidium thiocyanate. Lett Appl Microbiol 8:151-156

Plano GV, Barve SS, Straley SC (1991) LcrD, a membranebound regulator of the Yersinia pestis low-calcium response. J Bacteriol 173:7293-7303

Stuber K, Burr SE, Braun M, Wahli T, Frey J (2003a) Type III secretion genes in Aeromonas salmonicida subsp. salmonicida are located on a large thermolabile virulence plasmid. J Clin Microbiol 41

Stuber K, Frey J, Burnens AP, Kuhnert P (2003b) Detection of type III secretion genes as a general indicator of bacterial virulence. Mol Cell Probes 17:25-32

Vipond R, Bricknell IR, Durant E, Bowden TJ, Ellis AE, Smith M, MacIntyre S (1998) Defined deletion mutants demonstrate that the major secreted toxins are not essential for the virulence of Aeromonas salmonicida. Infect Immunol 66:1990-1998

Whitby PW, Landon M, Coleman G (1992) The cloning and nucleotide sequence of the serine protease gene (aspA) of Aeromonas salmonicida ssp. salmonicida. FEMS Microbiol Lett 78:65-71

Submitted: March 24, 2003; Accepted: August 7, 2003

Proofs received from author(s): September 25, 2003 